\author{
Agnieszka Łazicka \\ Wydział Filologiczny \\ Uniwersytet Mikołaja Kopernika w Toruniu \\ e-mail: a.lazicka@gmail.com \\ ORCID: 0000-0002-5837-1838
}

\title{
Dotyk, który „widzi”. Próba postawienia problemu
}

Problematyka ciała i cielesności to jedno z najważniejszych zagadnień współczesnej humanistyki. Choć fakt ten wydaje się zupełnie oczywisty, nie sposób zapomnieć o negatywnym punkcie odniesienia dla charakterystyki obecnego stanu rzeczy. Filozoficzne zaplecze zainteresowań współczesnej humanistyki ma długą historię, którą współtworzą również propozycje $\mathrm{w}$ zasadzie już nieaktualne - jeśli $\mathrm{w}$ dalszym ciągu inspirujące, to przede wszystkim dlatego, że jednak pobrzmiewała w nich przywoływana także współcześnie idea przezwyciężenia ugruntowanych w tradycji nowożytnej sposobów myślenia ${ }^{1}$. Otóż ważnym aspektem obecnych tendencji jest sprzeciw wobec zagubienia wielowymiarowej roli ciała na płaszczyźnie ontologicznej, jak i poznawczej, a także wobec ujemnego wartościowania cielesności względem niematerialnego składnika istoty ludzkiej. Aktualnie oczywiste zainteresowania są więc rezultatem rozmaitych prób odzyskania ciała dla humanistyki.

W kontekście badań nad poetycką twórczością Zbigniewa Herberta potrzeba odzyskania cielesności nabiera dodatkowego znaczenia. Jak pisze Radosław Sioma w szkicu "Á̇ runq świata ściany cztery”. Epikurejskie źródła

\footnotetext{
1 Odpowiednim przykładem może być filozofia E. Husserla. Zob. M. Drwięga, Między bryła cielesna a żywym ciałem. Husserla rozważania o cielesności, w: tegoż, Ciało człowieka. Studium z antropologii filozoficznej, Kraków 2005, s. 79-112.
} 
sensualizmu poezji Zbigniewa Herberta, w potocznym wyobrażeniu liryczny dorobek autora Napisu redukowany jest przede wszystkim do zagadnień moralnych oraz - rzadziej (i jak wynika z dalszych partii przywoływanego tekstu: ze względu na refleksyjny charakter utworów) - filozoficznych ${ }^{2}$. To potoczne wyobrażenie, wobec którego badacz zajmuje polemiczną postawę, zostaje tu powiązane ze stwierdzeniem Aleksandra Fiuta, iż „w zestawieniu z eseistyką poezja Herberta przedstawia się tak, jak gdyby była trzymana na ostrej estetycznej diecie. [...] Daremnie szukać w wierszach zapisów olśnienia zmysłową urodą świata" ${ }^{3}$. Wedle krytycznej odpowiedzi autora szkicu wiersze Herberta uobecniają jednak nawet coś więcej niż owo olśnienie:

Nieporozumienie, które egzemplifikuje cytat z eseju Aleksandra Fiuta, polega na tym, że zmysłowość tej poezji, zarówno w epistemologicznym (powrót do naiwnego realizmu metafizycznego i nobilitacja poznania zmysłowego), jak i estetycznym (plastyczność opisu, obrazowość, [...]) nie tylko współwystępują w wierszach Herberta z filozoficzną refleksyjnością i wysokiej próby moralistyką. Teoriopoznawczy sensualizm jest przecież częścią wpisanego w twórczość Herberta [...] światopoglądu, tkwi niejako u jego podstaw, gdyż wiąże się z, również pomijanymi przez krytykę, kwestiami prawdy i fałszu, oczywistości i pewności ludzkiego poznania ${ }^{4}$.

W świetle wspomnienia o utrwalonych drogach recepcji interesująco brzmi początek rozważań Piotra Augustyniaka nad - by użyć określenia badacza - „ontologicznym przesłaniem” poety: „Zostawmy na boku trudne kwestie społeczne i narodowe, a nawet (o ile to możliwe) etyczne i estetyczne wpisane w poezję Herberta. Skoncentrujmy się zaś na tym, co w każdym światoobrazie stanowi element centralny, decydujący o wszystkim innym" 5 . Rozmyślania filozofa warto zestawić z przywoływanym wyżej opracowaniem nie tylko ze względu na podkreślaną w obydwu tekstach konieczność przyjrzenia się poezji Herberta pod względem samych podstaw fundującego ją światopoglądu. Chodzi tu o jeszcze inne podobieństwo, tym bardziej godne

2 R. Sioma, „Aż runą świata ściany cztery”. Epikurejskie źródła sensualizmu poezji Zbigniewa Herberta, w: tegoż, Krzesło i zmięta serweta. Szkice o twórczości Zbigniewa Herberta, Kraków 2017, s. 37.

3 A. Fiut, Poeta - eseista, w: Twórczość Zbigniewa Herberta, red. M. Woźniak-Łabieniec, J. Wiśniewski, Kraków 2001, s. 131.

4 R. Sioma, "Á̇ runa świata ściany cztery”, s. 38-39.

5 P. Augustyniak, "Wersety panteisty”. Ontologiczne przestanie Zbigniewa Herberta, w: Pojęcia kiełkujace z rzeczy. Filozoficzne inspiracje twórczości Zbigniewa Herberta, red. J.M. Ruszar, Kraków 2010, s. 75 . 
uwagi, że porównanie koncepcji obydwu autorów zdecydowanie zdominowałyby różnice.

Augustyniak nie stawia $\mathrm{w}$ punkcie wyjścia sprawy zmysłowego wymiaru liryki Herberta. W dalszym toku swoich rozważań również nie podejmuje - kluczowego dla tekstu Siomy - problemu uobecnienia w dziełach poety sensualnego aspektu świata. Kwestię zapowiadanych w cytowanym fragmencie prymarnych pytań o rzeczywistość filozof rozwija jednak w oparciu o wydobywane z poezji Herberta metaforyczne znaczenia wzroku i dotyku. W dużej mierze to właśnie za ich pomocą, zdaniem badacza, poeta wyraża swoje "ontologiczne przesłanie". Obydwaj autorzy - choć każdy z nich w odmienny sposób - zagadnienie zmysłów umieszczają zatem u samych podstaw poetyckiej refleksji Herberta o świecie.

Zagadnienie to, jako spełniające $\mathrm{w}$ twórczości poety ważną rolę, $\mathrm{w}$ istocie można rozpatrywać $\mathrm{z}$ różnych punktów widzenia. Uzasadnione wydaje się zarówno zainteresowanie zmysłami rozumianymi dosłownie, jak i rozmyślanie nad ich metaforycznym znaczeniem. Bez wątpienia wnikliwe odczytanie niektórych utworów umożliwia interpretacja w świetle twierdzenia Józefa Marii Ruszara:

Przejście od zmysłu do alegorii jest możliwe, ponieważ od zawsze tak było w kulturze: świat zmysłów odsyłał do świata symboli. To, co widzialne, dotykalne, słyszalne - może posiadać podwójne znaczenie. Wzrok umożliwia oświecenie, dotyk daje pewność wątpienia, a słuch objawienie, czyli wysłuchanie transcendencji. Herbert po prostu wpisuje się w wielką tradycję zarówno Biblii, jak mędrców greckich ${ }^{6}$.

Niemniej jednak wiele przemawia za tym, by podstawy światopoglądu wpisanego w poezję Herberta związać $\mathrm{z}$ kontekstem dosłownego rozumienia zmysłów i percepcji. Liryka ta nie tylko ujawnia zmysłowy wymiar rzeczywistości, ale - co ważniejsze - wyraźnie łączy go z podłożem wszelkiego doświadczenia. Nie chodzi tu nawet o argumenty płynące $z$ wierszy o tematyce poznawczej. Rzecz w tym, że sprawa postrzegania zmysłowego okazuje się ważna również dla tych utworów, w których poeta ani nie problematyzuje sensualnej strony świata, ani nie koncentruje się ściśle na przedmiocie sensualnego doznania. Wyrazistych przykładów znajdziemy wiele już w samej Strunie światła. Warto przywołać chociażby Trzy wiersze z pamięci („,co dzień odnawiam spojrzenie / co dzień narasta mój dotyk / łaskotany bliskością

\footnotetext{
6 J.M. Ruszar, Zmysty i metafory. Hierarchia zmysłów wedtug Zbigniewa Herberta, w: Zmyst wzroku, zmyst sztuki. Prywatna historia sztuki Zbigniewa Herberta, cz. 1, red. J.M. Ruszar, Lublin 2006, s. 256.
} 
tylu rzeczy"7), Dom („dom był lunetą dzieciństwa / dom był skórą wzruszenia”) [s. 8] czy Czerwona chmurę („by znieść bolesną bliznę / między okiem a wspomnieniem") [s. 15].

Poetycka refleksja Herberta zdaje się być oparta na odczuciu cielesnego zapośredniczenia relacji między człowiekiem a światem. Niewykluczone więc, że w celu zgłębienia wskazanego zagadnienia należy pytać nie tylko o metaforyczne znaczenie zmysłów, lecz również - a może przede wszystkim - o metaforyczny sposób mówienia o zmysłach jako zmysłach. Trzeba bowiem dodać, że sensualny wymiar świata poezja ta ukazuje dość osobliwie. Jest to związane chociażby z tym, w jaki sposób mówi się tu o dotyku. Tej właśnie sprawie chciałabym przyjrzeć się nieco bliżej. Prezentowane rozważania nie będą zmierzały do rozwiązania konkretnego problemu. Niniejszy krótki tekst stanowi jedynie fragmentaryczną próbę wyprowadzenia kwestii, które mogłyby okazać się istotne $\mathrm{w}$ przypadku pracy nad obszerniejszym studium o wymiarach zmysłowości w liryce autora Napisu. W ramach tego szkicu pragnę wskazać kilka ważnych, jak sądzę, momentów w poetyckim namyśle Herberta nad dotykiem. Chodzi o wydobycie punktów, które jawią się jako godne uwagi, gdy zastanawiamy się nad podstawą powiązania tego zmysłu ze zdolnością widzenia.

2.

W przywoływanym wcześniej artykule Piotr Augustyniak próbuje opisać Herbertowską ontologię w oparciu o przeciwstawienie wzroku i dotyku. Odrzucając możliwość powiązania koncepcji poety z myśleniem realistycznym, badacz wyklucza uznanie zmysłu wzroku za kluczową dla jej zrozumienia kategorię:

człowiek w ujęciu realistycznym to byt mający zdolność opisu świata przy pomocy pewnych reprezentacji. Może on tedy ująć rzecz w niej samej tylko pośrednio - za pośrednictwem tego, co ją reprezentuje. [...] Stając się dla rzeczy podmiotem, ustanawia ją naprzeciw siebie (jako przedmiot) $\mathrm{w}$ nieprzekraczalnej odrębności. Skonstatujmy przy okazji: takie realistyczne ujęcie sposobu ludzkiego poznania doskonale odpowiada potocznemu sposobowi bycia i samorozumienia człowieka. Jeszcze jedna konstatacja: doskonałą, najczęściej przywoływaną metaforą tego realistycznego mechanizmu poznania jest zmysł wzroku. Ujmuje on bowiem zjawiska w pewnych obrazach vel wyglądach, które je reprezentują. [...]

7 Z. Herbert, Trzy wiersze z pamięci, w: tegoż, Wiersze zebrane, oprac. R. Krynicki, Kraków 2008 , s. 11. Kolejne cytaty z tego wydania umieszczam w tekście głównym, podając numery stron. 
Wedle Herberta, nie na tym jednak polega właściwy, poznawczy sposób obcowania człowieka z otoczeniem. Najlepszą metaforą jest tutaj nie wzrok, ale dotyk - jedyny w swoim rodzaju sposób „widzenia skórą" ${ }^{8}$.

Metafora dotyku miałaby oddawać „dążenie do bezpośredniości i zjednoczenia ze światem oraz wypełniającymi go przedmiotami" ${ }^{\text {. Ujmując }}$ wzrok i dotyk w relacji opozycji, Augustyniak mówi o metaforycznym wyrażaniu przez poetę polemicznej postawy wobec realistycznej wizji świata, w której rzeczy stoją "na zewnątrz, jako tożsame ze sobą, domknięte w swym sensie i odrębne" ${ }^{10}$. Zdaniem badacza poezja Herberta ukazuje w ten sposób napięcie między światopoglądem, który jednak narzuca się człowiekowi jako oczywisty, a „intuicją jakiejś innej ontologii" 11 .

Różnicę między wzrokiem i dotykiem w dość podobny sposób - lecz z całą pewnością mówiąc o zmysłach jako zmysłach - ujmuje Beata Przymuszała pod koniec rozdziału dotyczącego epistemologii Herberta, stanowiącego fragment większej pracy o dotyku w polskiej literaturze. Podsumowując część poświęconą autorowi Napisu, badaczka wpisuje jego twórczość w kontekst przemiany, jaka dokonała się w powojennej poezji:

w miejsce dominacji ujęć wzrokowych coraz częściej pojawia się dotyk jako „sposób patrzenia". Nie tyle jednak przeciwstawia się sile postrzegania, co zmienia rozkład akcentów. Dotyk wymaga przecież odmiennej postawy - nigdy nie dojdzie do konkluzji o tożsamości naszych ciał: bo dotykając czuje się i siebie, i Innego ${ }^{12}$.

Myślę, że podjęcie kwestii wzroku i dotyku niejako od podstaw - na gruncie twierdzenia o uobecnianiu przez poetę sensualnego podłoża doświadczenia - pozwoli zauważyć, że przeciwstawienie (czy chociażby wyraźne odróżnienie) tych dwóch zmysłów nie jest oczywiste. Nie tylko, jak sądzę, nie musimy postrzegać ich w relacji opozycji, lecz możemy nawet mówić o ich wzajemnym zbliżeniu. Niewykluczone, iż trzeba będzie uznać za znaczące również te cechy, które pozwalają budować na tych zmysłach metafory przydatne dla wyrażenia przeciwstawnych idei. Niemniej jednak może okazać się, że o przywołane przez Augustyniaka „widzenie skórą” warto

\footnotetext{
8 P. Augustyniak, "Wersety panteisty”, s. 79-80.

9 Tamże, s. 83.

10 Tamże, s. 81.

11 Tamże, s. 83.

12 B. Przymuszała, Dotyk, czyli czułość. Pana Cogito sposób na poznawanie świata, w: tejże, Szukanie dotyku. Problematyka ciała w polskiej poezji współczesnej, Kraków 2006, s. 202.
} 
pytać właśnie w kontekście powiązania dotyku ze wzrokiem na poziomie metaforycznego opisu.

3.

Relację między dotykiem a wzrokiem w poezji Herberta najbardziej bezpośrednio zdają się zarysowywać metaforyczne sformułowania przypisujące dotykowi zdolność widzenia. W utworze Poczucie tożsamości z tomiku Pan Cogito, mówi się o kamieniu (którego opis jest tak naprawdę opisem człowieka ${ }^{13}$ ): „ma tysiąc oczu z krzemienia / (porównanie bez sensu kamień widzi skórą)" [s. 373]. Z kolei Alienacje Pana Cogito, wiersz z tego samego zbioru, rozpoczyna się słowami:

Pan Cogito trzyma w ramionach
ciepłą amforę głowy
reszta ciała jest ukryta
widzi ją tylko dotyk [s. 388]

Zupełnie oczywiste stwierdzenie, że sformułowania te odnoszą się do percepcji, nie musi wcale prowadzić do potwierdzenia wstępnej intuicji. Być może widzenie należy tu zwyczajnie utożsamić ze spostrzeganiem i przyjąć, że wybór między dwoma określeniami nie ma w tym przypadku większego znaczenia? Metafory te dałoby się wówczas uznać za próbę oddania momentu, w którym percepcja spoczywa przede wszystkim na dotyku. Niewykluczone jednak, że widzenie rzeczywiście powinno zostać skojarzone z konkretnym zmysłem - zmysłem wzroku - i że kontekst ten dostarcza ważnych treści dla zrozumienia, jakie miejsce zajmuje dotyk w poezji Herberta. Sprawę tę pozostawmy na razie otwartą i przyjrzyjmy się wybranym fragmentom innych wierszy. Najlepszym punktem odniesienia dla kolejnych przykładów będzie zapewne utwór Dotyk z tomu Hermes, pies $i$ gwiazda.

W twórczości Herberta problem zmysłów pozwala wyodrębnić się nie tylko na tle ukazywania sensualnej strony rzeczywistości albo zdawania sprawy z faktu, że wszelkie doświadczenie ma cielesne podłoże. One same również stają się dla Herberta przedmiotem refleksji i, co szczególnie istotne,

13 Zob. tamże, s. 78-79; A. Łazicka, Afekt, percepcja i granice ciała. O wierszu „Poczucie tożsamości" Zbigniewa Herberta, w: „Zemsta ręki śmiertelnej”. Interpretacje wierszy poetów XX wieku, red. J.M. Ruszar, D. Siwor, Kraków 2017, s. 25-38. 
poeta nie traktuje ich wszystkich jako jednakowo ważnych ${ }^{14}$. W Przeczuciach eschatologicznych Pana Cogito z tomu Raport z oblężonego miasta na czele hierarchii ważności znajdują się dotyk i wzrok. W wierszu Dotyk na tle wszystkich zmysłów wyróżniony zostaje tylko ten jeden - przywołany w tytule:

wtedy przychodzi pewny dotyk
rzeczom przywraca nieruchomość
nad kłamstwo uszu oczu zamęt
dziesięciu palców rośnie tama
nieufność twarda i niewierna
układa palce w ranie świata
i od pozoru rzecz oddziela
o najprawdziwszy ty jedynie
potrafisz wypowiedzieć miłość
ty jeden możesz mnie pocieszyć
bośmy oboje głusi ślepi
- na skraju prawdy rośnie dotyk [s. 84-85]

Ze względu na metaforę, która została przywołana na początku tej części szkicu, jedno z określeń wybrzmiewa szczególnie wyraźnie. Otóż w tym wierszu mówi się, że dotyk jest ślepy. W przeciwieństwie do przykładów ze zbioru Pan Cogito powyższy fragment raczej zaprzecza wyobrażeniu obydwu zmysłów jako rzeczywiście sobie bliskich. Tym bardziej więc warto przypuścić, że nieprzypadkowo mówi się o dotyku, iż „widzi”. Jeśli nawet określenia te mają wyrażać idee przeciwstawne: $\mathrm{z}$ jednej strony przepaść, z drugiej bliskość między dotykiem i wzrokiem, niewykluczone, że każde $\mathrm{z}$ nich sięga innego poziomu Herbertowskiej refleksji. Bez wątpienia niezgodność ta, choćby tylko pozorna, zostaje zarysowana dość wyraźnie. O ile bowiem zgodzimy się, że niektóre utwory łączą dotyk ze zdolnością widzenia, nie tylko ten jeden wiersz będzie przeczyć takiej intuicji. W utworze Biaty kamień dotyk zostaje nazwany „ślepym zwierzęciem” [s. 113]. Istotny wydaje się również fragment wiersza Ścieżka, wart zacytowania ze względu na podejmowaną $\mathrm{w}$ nim tematykę poznawczą:

jeśli wybrać źródło szło się po stopniach mroku w coraz głębszą ciemność wiódł na oślep dotyk do matki elementów którą uczcił Tales by w końcu pojednać się z wilgotnym sercem rzeczy $\mathrm{z}$ ciemnym ziarnem przyczyny [s. 325]

14 Zob. T. Tomasik, Mistrz empirii. Niewierny Tomasz według Herberta, w: „Gąszcz srebrnych liści”. Interpretacje wierszy Zbigniewa Herberta, red. J.M. Ruszar, Kraków 2015, s. 53-68; J.M. Ruszar, Zmysty i metafory. 
W tym momencie chciałabym jednak wrócić do utworu Dotyk. Tytułowy zmysł zostaje w nim nazwany „pewnym” i „najprawdziwszym”. Te określenia mają wyróżnić go na tle pozostałych zmysłów, których opis rozpoczyna się od fragmentu poświęconego wzrokowi:
przez oczy idzie karawana obrazów
są jak widok w wodzie
i między czernią między bielą
kolorów sypie się niepewność
nasz wzrok jest lustrem albo sitem
przez który sączy się powoli
wilgotnych oczu chwiejna mądrość

Spróbujmy uchwycić związek między kilkoma metaforami. Wiersz otwierają słowa: „Podwójna wszystkich zmysłów prawda”. Zacytowany fragment zdecydowanie nawiązuje do tej myśli. Sugeruje bowiem, że wzrok może pomylić rzecz z jej obrazem. Z tym wyobrażeniem - lecz oczywiście w kontekście przezwyciężenia owej niedoskonałości - łączy się też opis dotyku jako zmysłu, który „od pozoru rzecz oddziela”.

Podobną ideę wyraża fragment opisu stwarzania świata w wierszu Kłopoty matego stwórcy z tomiku Struna światła:

\section{krzyknąłem kiedy obraz skały potwierdził najprawdziwszy dotyk [s. 51]}

Oprócz tego, że i tutaj dotyk zostaje nazwany „najprawdziwszym”, cecha ta ponownie ujawnia się jakby w przestrzeni rzeczy i ich obrazów, za której powstanie odpowiada zdolność widzenia. Jednak $\mathrm{w}$ tym wierszu różnica między rzeczą a jej obrazem raczej nie pojawia się po to, by ukazać wzrok jako zmysł niedoskonały i omylny. Ów rozziew pozostaje niejako w sferze możliwości, podczas gdy na pierwszy plan wysuwają się emocje związane właśnie z potwierdzeniem świadectwa oczu przez dotyk.

Opierając się na wyraźnym podobieństwie między tymi utworami, można chyba uznać, że we wcześniej omawianym wierszu wyróżnienie wzroku również nie polega na radykalnym przeciwstawieniu go innym zmysłom. Korzysta on z ich świadectwa. Jest „najprawdziwszy”, a nie „jedyny prawdziwy". Nie kieruje nim odgórna zasada odrzucenia błędu, która miałaby swoje źródło poza samym doświadczeniem. Dotyk „układa palce w ranie świata” i „od pozoru rzecz oddziela”, a zatem nie walczy z „podwójną prawdą" zmysłów, lecz raczej nieustannie uczestniczy w jej rozpoznawaniu ${ }^{15}$.

15 Pisałam o tym w tekście Wokół uznania realności świata. Poezja Zbigniewa Herberta a fenome- 
Obydwa utwory bez wątpienia podkreślają pewną różnicę. Dotyk bezpośrednio zbliża się do rzeczy, natomiast wzrok ujmuje ją z dystansu. Bezpośredniość pozwala odsunąć od rzeczy zniekształcające ją obrazy, dystans naraża na wzięcie ich za rzecz. Z tą różnicą wiąże się kolejne określenie pojawiające się w wierszu Dotyk. Tytułowy zmysł „rzeczom przywraca nieruchomość". Bezpośrednie zetknięcie jest równoznaczne z dotarciem do "czegoś”, co można wziąć bez wątpienia za "takie, a nie inne", a na uzyskanie tej pewności pozwala świat, który pod jakimś względem daje się rozpoznać jako stały. Problem rozwinięcia tej kwestii wybiega poza ramy niniejszego szkicu. W związku z przywołaną właśnie metaforą czas przejść do innego utworu, w którym pojawia się podobne sformułowanie.

Mowa o wierszu Stołek z pierwszego tomiku poety. W wersach zamykających ów liryk osoba mówiąca kieruje do tytułowego stołka następujące słowa:

jak ci wyrazić moją wdzięczność podziw przychodzisz zawsze na wołanie oczu nieruchomością wielką tłumacząc na migi biednemu rozumowi: jesteśmy prawdziwi na koniec wierność rzeczy otwiera nam oczy [s. 55]

Tym razem „nieruchomość” wyraźnie związana jest ze wzrokiem, a raczej: także ze wzrokiem. We fragmencie, który najczytelniej ujawnia podejmowaną $\mathrm{w}$ tym wierszu polemikę $\mathrm{z}$ idealizmem, przywołane zostają bowiem dwa zmysły:

- wiesz mój kochany byli szarlatani

którzy mówili: kłamie ręka kłamie

oko kiedy dotyka kształtów co są pustką - [s. 55]

Nie tylko wspomina się o wspólnym działaniu dotyku i wzroku, lecz również mówi się o tym, że i wzrok może dotykać. W świetle wcześniej omawianych utworów metafora ta zdaje się sugerować, iż widzenie jest w jakiś sposób ukierunkowane na pewność daną w bezpośrednim zbliżeniu.

W kontekście polemiki z idealizmem „nieruchomość” bez wątpienia wolno połączyć z wyrazem przekonania o transcendentności rzeczy względem podmiotu. W wersie "przychodzisz zawsze na wołanie oczu” zbiegają się dwie istotne kwestie: niezależność tytułowego stołka (bo każdora-

nologia Romana Ingardena, w: Liryka i fenomenologia. Zbigniew Herbert i Tadeusz Różewicz w kręgu myśli Ingardenowskiej, red. J.M. Ruszar, D. Siwor, Kraków 2016, s. 103. Tam również omawiam wiersz Stołek w kontekście polemiki Herberta z idealizmem [s. 103-104]. 
zowo daje się on rozpoznać jako ten sam przedmiot) od świadomości patrzącego oraz zupełna oczywistość tej niezależności stwierdzana dzięki zmysłom. Utwory Dotyk oraz Kłopoty małego stwórcy, z jednej strony pozwalają ująć wzrok i dotyk w relację opozycji. Chodzi rzecz jasna o wskazaną już różnicę między dystansem a zbliżeniem. $Z$ drugiej strony jednak metafory wyrażające to napięcie oddają również oczywistą dla zmysłów zewnętrzność świata wobec podmiotu. Dotyk potwierdza istnienie tego, co ze względu na dystans związany z widzeniem, zostaje ukazane jako wyraźnie oddzielone od postrzegającego.

Być może w wierszu Dotyk najistotniejsze jest właśnie potwierdzenie istnienia świata? Do najważniejszego ze zmysłów skierowane są słowa: „ty jedyny potrafisz wypowiedzieć miłość". Utwór Stołek, w którym otwarcie został poruszony ten problem, rozpoczyna się od wyznania: „W końcu nie można ukryć tej miłości". Dotyk byłby wówczas wyjątkowy jako taki zmysł, który zawsze zakłada tę bezpośrednią bliskość rzeczy, zapewniającą o istnieniu świata poza podmiotem.

4.

Czy wskazane aspekty ontologiczno-poznawczej refleksji Herberta rzeczywiście mają znaczenie dla zrozumienia utworów, w których zmysł dotyku obdarzony zostaje zdolnością widzenia? Czy ta metafora może rzucić nowe światło na omawiane dotychczas wiersze? Wiele przemawia za udzieleniem pozytywnej odpowiedzi na obydwa pytania. Zarówno w Poczuciu tożsamości, jak i w Alienacjach Pana Cogito sformułowania dotyczące "widzącego" dotyku rzeczywiście wprowadzają problem cielesności. Chociaż obydwa wiersze zdają się poruszać kwestię otwierania się na Innego, rozważania nad tym tematem najprawdopodobniej stanowią przedłużenie myśli dotyczącej samych podstaw światopoglądu. W opisie kamienia w utworze Poczucie tożsamości poeta najprawdopodobniej próbuje sięgnąć afektywnego wymiaru międzyludzkiej relacji ${ }^{16}$ :

nie była to wcale idea niezmienności kamień

był różny [...]

potem pił deszcz łapczywie $\mathrm{i}$ te zapasy $\mathrm{z}$ wodą

słodkie unicestwienie zmaganie żywiołów spięcia elementów

zatracania natury własnej pijana stateczność

były zarazem piękne i upokarzające [s. 373]

16 Omawiam to szczegółowo w tekście Afekt, percepcja i granice ciała, s. 25-38. 
W Alienacjach Pana Cogito interesująca nas metafora również ma za zadanie otworzyć zmysłowy wymiar osobowej relacji. Ukazuje ona, co zauważa Sioma, „fizyczną bliskość dwojga kochanków”. Ponadto, jak pisze badacz, „wers: «widzi ją tylko dotyk», to precyzyjna synestezja, oparta na naturalnej zdolności wyobraźni do rekonstruowania kształtów na podstawie dotyku"17. Warto $\mathrm{w}$ tym momencie zwrócić uwagę na inny utwór $\mathrm{z}$ tego samego tomiku, mianowicie na prozę Pan Cogito a perła. Również tutaj Herbert zdaje się wskazywać na pewien związek między dotykiem a wyobrażeniem wzrokowym. Oto co dzieje się, gdy do buta tytułowego bohatera wpada mały kamyk:

Na początku wyglądało to niegroźnie, po prostu doskwieranie i nic więcej, ale po jakimś czasie w polu świadomości pojawiła się pięta, i to w momencie, kiedy młody Cogito mozolnie chwytał myśl profesora rozwijającego temat pojęcia idei u Platona. Pięta rosła, nabrzmiewała, pulsowała, z bladoróżowej stawała się purpurowa jak słońce, wypierała z głowy nie tylko ideę Platona, ale wszystkie inne idee [s. 372].

Zanim wrócimy do tego przykładu, spójrzmy na jeszcze inną kwestię. Obydwa wiersze, które zostały w tej części wspomniane jako pierwsze, $\mathrm{z}$ jednej strony mówią o bliskości. W Poczuciu tożsamości chodzi zapewne o wrażenie utożsamienia się z kimś innym, związane z odczuciem umieszczenia się w czyimś ciele. W utworze Alienacje Pana Cogito również wspomina się o momentach intymności tak głębokiej, że granice ciała mogą wydawać się nieoczywiste. Jednak z drugiej strony to, co niesamowicie bliskie, pozostaje na zewnątrz. Kamień, który „widzi skórą” - będący metaforą człowieka - odzyskuje swoją tożsamość: „więc w końcu trzeźwiał w powietrzu suchym od piorunów" [s. 373]. Wiersz Poczucie tożsamości koresponduje zapewne z sąsiadującym w nim na kartach tomiku utworem Siostra. Rozważania o podobieństwie Pana Cogito do tytułowej postaci podsumowują słowa:

skończyło się na dotyku dotyk się nie otworzył

i Pan Cogito pozostał w granicach swojej skóry [s. 371]

Ten sam wiersz pokazuje jednak przekroczenie granic swojego ciała, $i$ to właśnie w związku ze wzrokowym spostrzeżeniem:

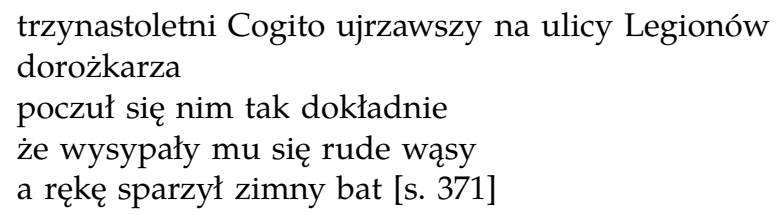

17 R. Sioma, "Aż runq świata ściany cztery”, s. 41. 
W Alienacjach Pana Cogito z kolei tytułowy bohater:

\author{
jeszcze raz \\ stwierdza ze zdumieniem \\ że istnieje ktoś poza nim \\ nieprzenikniony jak kamień [s. 388]
}

Choć wspomniane przed chwilą utwory nawiązują do przekraczania granic ciała, a więc zarysowują pewien przykład opozycji między dystansem a zbliżeniem, trudno byłoby ustawić $\mathrm{w}$ tej relacji odpowiednio wzrok i dotyk. Zmysł dotyku można by raczej połączyć z niezbywalną (w świetle wierszy omawianych wcześniej) cechą sposobu zanurzenia człowieka w świecie $\mathrm{z}$ oczywistym poczuciem istnienia świata poza podmiotem, danym $\mathrm{w}$ bezpośrednim zbliżeniu. Dotyk jak najbardziej wskazuje tu więc na zewnętrzność. Poza tym nie chodzi też chyba o przeciwstawienie momentów otwarcia cielesnych granic postrzeganiu wzrokowemu. Przecież to właśnie „dotyk się nie otworzył".

Co więcej, jak sugeruje omawiana metafora, najbardziej odpowiednią formą dla określenia tego, co zewnętrzne, jest wyobrażenie wzrokowe. Sądzę, że przywoływane w poprzedniej części wiersze również przygotowują podstawy dla tego stwierdzenia. Jednak kiedy mówi się, że to właśnie dotyk „widzi”, zapewne chodzi też o podkreślenie braku czegoś istotnego dla samego widzenia. W utworach Alienacje Pana Cogito oraz Pan Cogito a perła dotyk doświadcza tego, co zewnętrzne, jako rzeczy możliwej do zobaczenia, ale to wzrokowe wyobrażenie trudno byłoby porównać do wyraźnie stojącego przed oczyma obrazu. Ale czy to oczywiste stwierdzenie nie prowadzi jednak do pytania o samą podstawę mówienia o zmysłach? Dotyk mógłby „widzieć", postrzegać rzeczy jako możliwe do oglądania, bo nawet wzrok - który ujmuje je wyraźnie, rzeczywiście stawia je przed oczyma - chwytałby raczej ich ogólną postać. Czy Herbert nie próbuje pokazać, że widzenie (ale też inne władze zmysłowe) nie jest syntetyzowaniem pojedynczych wrażeń? Czy poezja ta nie oddaje myśli, że $\mathrm{w}$ bezpośrednim doświadczeniu nie uchwytujemy związków poszczególnych obiektywnych jakości, lecz pewne całości od razu obdarzone sensem?

Nawiązuję tu do koncepcji postrzegania zaproponowanej przez Maurice'a Merleau-Ponty'ego w jego obszernym dziele Fenomenologia percepcji ${ }^{18}$.

18 W kilku swoich tekstach wskazywałam już na możliwość czytania poezji Herberta w kontekście kategorii bezpośredniego doświadczenia zaproponowanej przez M. Merleau-Ponty'ego. Przygotowując niniejszy szkic na temat zmysłu dotyku, znalazłam dwa opracowania, które mogłyby potwierdzać ten trop. Na podobieństwo poezji Herberta i filozofii Merleau-Ponty'ego 
Francuski filozof polemizuje z idealizmem i empiryzmem, formułując wobec nich zarzut, który ujawniać ma podobieństwo między tymi skrajnie przeciwstawnymi stanowiskami. W obydwu przypadkach obecny w postrzeżeniu przedmiot opisywany jest jako gotowy, określony i skończony. Intelektualizm sprowadza go do zbioru jakości, które obecne są już w świadomości. Empiryzm widzi w nim zbiór jakości obecnych obiektywnie w świecie, odtwarzany dzięki działaniu przedmiotu na organy zmysłowe.

Postawione wyżej kwestie są zatem jednocześnie pytaniem o to, czy w poezji Herberta - tak jak w filozofii Merleau-Ponty'ego - nie kryje się myśl, że w postrzeganiu każdorazowo uczestniczy ciało jako całość. Nie jest to pytanie, czy rzeczywiście, zdaniem poety, ciało odgrywa ważną rolę $\mathrm{w}$ poznaniu. Ta sprawa została określona już w punkcie wyjścia. Chodzi o rzecz ściśle związaną ze strukturą doświadczenia percepcyjnego. Warto zastanowić się, czy sposób, w jaki poeta opisuje dotyk i wzrok, nie wymaga odwołania się do kategorii schematu ciała z filozofii Maurice'a Merleau-Ponty'ego. Na podstawie wydobytych kwestii można bowiem przypuścić, że istotny okaże się tu kontekst cielesnej integracji zmysłów ${ }^{19}$.

wskazali B. Przymuszała oraz J.M. Ruszar w tekstach, które były przywoływane w niniejszym artykule. Spostrzeżenia badaczy są niezwykle ważne i inspirujące. Autorzy trafnie uzasadniają sięgnięcie po kontekst filozofii Merleau-Ponty'ego, mówiąc o ucieleśnionym poznaniu oraz o próbie przekroczenia opozycji idealizmu i empiryzmu w twórczości obydwu myślicieli. Na uwagę zasługuje zwłaszcza spostrzeżenie Przymuszały, że tak u Merleau-Ponty'ego, jak u Herberta cielesność nie tyle bierze udział w poznaniu, co po prostu je warunkuje. Ruszar zauważa ponadto, że dla obydwu twórców postrzeganie jest sprawą całego ciała, a nie poszczególnych zmysłów (problem w tym, że badacz zdaje się wykorzystywać to podobieństwo na rzecz tezy o odchodzeniu przez poetę od dosłownego rozumienia zmysłów, a ponadto nie uwzględnia tego, że według Merleau-Ponty'ego sens pochodzi od samego bytu). Autorzy nie przywołują jednak wprost kluczowej dla porównania kategorii bezpośredniego doświadczenia i nie omawiają szczegółowo struktury tego doświadczenia jako doświadczenia percepcyjnego (choć oczywiście przykładając filozofię Merleau-Ponty'ego do spostrzeżenia, że poznawanie u Herberta nie jest ani czysto umysłowe, ani czysto zmysłowe, opisują wnikliwie pewne jego elementy). Innymi słowy, nie zostaje tu wyjaśnione, na czym, według francuskiego filozofa, polega błąd tak idealizmu, jak empiryzmu w opisie percepcji. W związku z tym odwołania do rozważań Merleau-Ponty'ego nie wiążą się z dostatecznym wyjaśnieniem, na czym - w kontekście tej koncepcji filozoficznej - miałaby polegać różnica między stanowiskiem Herberta a empiryzmem (oraz, rzecz jasna idealizmem, co jest tu akurat mniej istotne, gdyż badacze skupiają się na zmysłowym wymiarze poznania). Ta uwaga nie ma charakteru zarzutu. Zamysł autorów polegał na wskazaniu jedynie pewnego pokrewieństwa myślowego - ścisłe podobieństwo postawiono pod znakiem zapytania. Sądzę jednak, że porównanie twórczości poety i filozofa można przeprowadzić w oparciu o same podstawy ich refleksji ontologiczno-poznawczej. Niniejszy tekst stanowi zaledwie przygotowanie do szczegółowego porównania, które warto rozpocząć od sprawdzenia, czy do zrozumienia poezji Herberta nie przybliży nas opis tego, co zdaniem Merleau-Ponty'ego zachodzi w źródłowym, bezpośrednim doświadczeniu [zob. M. Merleau-Ponty, Fenomenologia percepcji, przeł. M. Kowalska, J. Migasiński, Warszawa 2001]. 
Inną ważną sprawą, która pozostaje otwarta, jest problem określenia funkcji wzroku i dotyku. To pozwoli zapewne dokładniej przyjrzeć się metaforom i umieścić je na odpowiednich poziomach refleksji Herberta nad zmysłami. Niniejszy szkic stanowi jedynie wstęp do rozpoznania proponowanej przez poetę refleksji ontologiczno-poznawczej. Jego główny cel polega na pokazaniu, że analiza metafory widzącego dotyku dostarcza argumentów na rzecz twierdzenia, iż poetycki światopogląd Herberta rodzi się w oparciu o zmysły - związane rzeczywiście z cielesnym wymiarem istnienia.

\section{Bibliografia}

Augustyniak Piotr (2010), „Wersety panteisty”. Ontologiczne przestanie Zbigniewa Herberta, w: Pojęcia kiełkujące z rzeczy. Filozoficzne inspiracje twórczości Zbigniewa Herberta, red. J.M. Ruszar, Kraków: Wydawnictwo Platan, s. 75-99.

Drwięga Marek (2005), Między bryłą cielesną a żywym ciałem. Husserla rozważania o cielesności, w: M. Drwięga, Ciało człowieka. Studium z antropologii filozoficznej, Kraków: Księgarnia Akademicka, s. 79-112.

Łazicka Agnieszka (2016), Wokót uznania realności świata. Poezja Zbigniewa Herberta a fenomenologia Romana Ingardena, w: Liryka i fenomenologia. Zbigniew Herbert i Tadeusz Różewicz w kręgu myśli Ingardenowskiej, red. J.M. Ruszar, D. Siwor, Kraków: Instytut Myśli Józefa Tischnera, s. 93-107.

Łazicka Agnieszka (2017), Afekt, percepcja i granice ciała. O wierszu „Poczucie tożsamości” Zbigniewa Herberta, w: „Zemsta ręki śmiertelnej”. Interpretacje wierszy poetów XX wieku, red. J.M. Ruszar, D. Siwor, Kraków: JMR Trans-Atlantyk, Instytut Myśli Józefa Tischnera, s. 25-38.

Merleau-Ponty Maurice (2001), Fenomenologia percepcji, przeł. M. Kowalska, J. Migasiński, Warszawa: Fundacja Aletheia.

19 Naturalnie, ten problem, jako dopiero zapowiadany, nie zostanie tu rozwinięty. Dla wyjaśnienia, dlaczego podjęte rozważania przygotowują podstawy dla wyprowadzenia tej kwestii, zamieszczam cytaty dotyczące fundamentów myśli Merleau-Ponty'ego. „Merleau-Ponty podkreśla, że to ciało jest podmiotem percepcji i źródłem jedności zmysłów, choć każdy organ bada przedmiot na swój sposób..." [zob. S. Nowacka-Dobosz, J. Femiak, B. Pędraszewska-Sołtys, Rola ciała w kształtowaniu świadomości. Inspiracje filozoficzne i naukowe, „Rozprawy Naukowe Akademii Wychowania Fizycznego we Wrocławiu” 2015, nr 48, s. 58]. „W przypadku ciała własnego nie dysponujemy jego pojęciowym przedstawieniem. Przeżywana jedność ciała jest jednością funkcjonalną. Nie pojawia się ona na skutek świadomego łączenia jego części - poprzez akumulacje doświadczeń wzrokowych i dotykowych - w całość. Poszczególne części ciała dokonują względem siebie "przekładu « bez pośrednictwa świadomości tematycznej" [zob. Z.P. Zwoliński, Pojęcie ciała własnego i jego status w "Fenomenologii percepcji” Merleau-Ponty'ego, "Tekstoteka Filozoficzna" 2015, nr 4, s. 19]. 
Nowacka-Dobosz Sylwia, Femiak Joanna, Pędraszewska-Sołtys Barbara (2015), Rola ciała w kształtowaniu świadomości. Inspiracje filozoficzne i naukowe, „Rozprawy Naukowe Akademii Wychowania Fizycznego we Wrocławiu", nr 48, s. 56-62.

Przymuszała Beata (2006), Dotyk, czyli czułość. Pana Cogito sposób na poznawanie świata, w: B. Przymuszała, Szukanie dotyku. Problematyka ciała w polskiej poezji współczesnej, Kraków: Universitas, s. 190-203.

Ruszar Józef Maria (2006), Zmysty i metafory. Hierarchia zmysłów według Zbigniewa Herberta, w: Zmyst wzroku, zmyst sztuki. Prywatna historia sztuki Zbigniewa Herberta, cz. 1, red. J.M. Ruszar, Lublin: Wydawnictwo Archidiecezji Lubelskiej Gaudium, s. 244-273.

Sioma Radosław (2017), „Aż runq świata ściany cztery”. Epikurejskie źródła sensualizmu poezji Zbigniewa Herberta, w: R. Sioma, Krzesło i zmięta serweta. Szkice o twórczości Zbigniewa Herberta, Kraków: JMR Trans-Atlantyk, Instytut Myśli Józefa Tischnera, s. 37-60.

Tomasik Tomasz (2015), Mistrz empirii. Niewierny Tomasz wedtug Herberta, w: „Gąszcz srebrnych liści". Interpretacje wierszy Zbigniewa Herberta, red. J.M. Ruszar, Kraków: JMR Trans-Atlantyk, s. 53-67.

Zwoliński Zbigniew Paweł (2015), Pojęcie ciała własnego i jego status w "Fenomenologii percepcji” Merleau-Ponty'ego, "Tekstoteka Filozoficzna” nr 4, s. 14-22.

\section{The "Seeing" Touch. A Reconnaissance}

\section{Summary}

The paper is intended as preparation for a detailed analysis of Zbigniew Herbert's reflection on ontology and epistemology. An initial assumption is that the poet tries to evoke the sensual dimension of experience in his poetry. The main focus of the analysis is the metaphor of touch that "sees". It is conceivable that through this metaphor Herbert expresses a connection between touch and sight.

Keywords: polish poetry, senses, touch, sight, perception 